\title{
CONSTRUCTION AND CHARACTERIZATION OF A Burkholderia pseudomallei wzm DELETION MUTANT
}

by

Yuen Chee Wah

Thesis submitted in fulfillment of the requirements

for the degree of

Master of Science

October 2010 


\section{ACKNOWLEDGEMENTS}

I would like to thank Prof Dr. Nazalan Najimudin for giving me the opportunity to complete my masters degree in his laboratory and for serving as my supervisor. Prof. Nazalan has always been available for advice and support. I have greatly enjoyed working in his lab and I have received invaluable education in the field of molecular genetics.

I would like to thank the past and present members of the lab for their help and friendship during the whole duration of my masters degree. Many thanks go to Dr Suriani, Dr. Razip, Hok Chai, Ainihayati, Kamariah Hasan, Balqis, Yifen, Eng Keat, Tee and Afiqah for their invaluable advices in molecular biology and microbiology.

My acknowledgements would not be complete without expressing my endless gratitude to my family for their support they have offered me throughout the duration of my study. Special thanks to my Dad, Mom, grandfather, grandmother and my aunt. I would like to thank my girl friend, Mei Mei, for her patience and support. Thank you once again for their tremendous support. 


\section{TABLE OF CONTENTS}

PAGES

$\begin{array}{ll}\text { Acknowledgements } & \text { ii }\end{array}$

Table of Contents iii

List of Tables vii

List of Figures viii

List of Plates $\quad$ ix

Symbols and abbreviations $\quad x$

Abstrak xiv

Abstract $\quad$ XV

1.0 INTRODUCTION 1

\subsection{LITERATURE REVIEW}

2.1 Burkholderia pseudomallei 3

$\begin{array}{ll}2.2 \text { Habitat } & 6\end{array}$

$\begin{array}{ll}\text { 2.3 Melioidosis } & 7\end{array}$

2.4 Melioidosis in animals 8

$\begin{array}{ll}2.5 \text { Treatment of melioidosis } & 8\end{array}$

$\begin{array}{ll}\text { 2.6 Diagnosis of melioidosis } & 10\end{array}$

2.7 Virulence determinants of Burkholderia pseudomallei 11

$\begin{array}{ll}\text { 2.7.1 Secreted Antigens } & 15\end{array}$

$\begin{array}{ll}\text { 2.7.2 Cell-walled associated antigens } & 18\end{array}$

2.8 Burkholderia pseudomallei capsular polysaccharide 20

2.8.1 Roles of bacterial capsule in Burkholderia pseudomallei 21 

of B. pseudomallei

2.9 Genetic tools for studying virulence determinants

2.10 Objectives of study

\subsection{MATERIALS AND METHODS}

$\begin{array}{ll}3.1 \text { Chemicals } & 38\end{array}$

3.2 Bacterial strains, plasmids and growth conditions 39

$\begin{array}{ll}3.3 \text { General methods } & 39\end{array}$

3.3.1 Sterilization of apparatus $\quad 39$

$\begin{array}{ll}3.4 \text { Primers } & 40\end{array}$

$\begin{array}{ll}3.5 \text { Culture media } & 44\end{array}$

3.5.1 Luria Bertani (LB) medium and agar 44

3.5.2 Blomfield medium and agar $\quad 44$

3.5.3 M9 minimal medium 44

3.6 General molecular biology methods 45

3.6.1 Restriction enzyme digestion of DNA 45

3.6.2 Ligation of DNA 45

$\begin{array}{ll}\text { 3.6.3 Electrophoresis } & 45\end{array}$

3.6.4 Transformation $\quad 46$

3.6.5 Burkholderia pseudomallei genomic DNA extraction 47

$\begin{array}{ll}\text { 3.6.6 Plasmid DNA extraction } & 48\end{array}$

3.6.7 Polymerase Chain Reaction (PCR) 48

3.6.8 PCR product purification $\quad 49$ 
3.6.9 DNA sequencing

3.6.10 Construction of $w z m$ gene deletion construct, pCW110

3.7 Construction of unmarked and in-frame deletion of $w z m$ in $B$. pseudomallei UKMS-01

3.8 Phenotypic characterization of acapsular mutant strain ( $w z m$ gene) of Burkholderia pseudomallei

3.8.1 Growth curve of B. pseudomallei UKMS-01 and CW-01

3.8.2 Transmission electron microscopy 52

3.8.2 Scanning electron microscopy

3.8.3 Biofilm formation assay 55

3.8.4 Bacterial cell aggregation assay 56

3.8.5 Desiccation survival assay 56

3.8.6 Sensitivity to oxidative stress 57

3.8.7 Osmotic stress assay 57

3.8.8 Sensitivity to low $\mathrm{pH}$ 58

\subsection{RESULTS}

4.1 Markerless deletion of Burkholderia pseudomallei wzm gene 59

4.2 Phenotypic characterization of acapsular mutant strain ( $w z m$ gene) of

Burkholderia pseudomallei

4.2.1 Growth of B. pseudomallei UKMS-01 and CW-01 cultured in

LB and M9 medium supplemented with glucose

4.2.2 Transmission electron microscopy 
4.2.5 Desiccation survival assay

4.2.6 Sensitivity to oxidative stress

\subsection{DISCUSSION}

5.1 Introduction

5.2 Construction of an unmarked deletion of $w z m$ gene in $B$. pseudomallei

5.3 Phenotypic characterization of B. pseudomallei wzm mutant

\subsection{Summary and future research directions}

6.1 Summary of the study

6.2 Suggestions for future studies

$\begin{array}{lr}\text { REFERENCES } & 98\end{array}$

$\begin{array}{ll}\text { APPENDICES } & 114\end{array}$ 


\section{LIST OF TABLES}

PAGES

Table 2.1 List of virulence factors that are identified in $B$.

14

pseudomallei

Table 2.2 Genes involved in producing and exporting capsule in $B$.

pseudomallei

Table 3.1 List of chemicals and suppliers

Table $3.2 \quad$ Bacterial strains and plasmids

Table 3.3 (a) Oligonucleotides designed based on genomic sequence of $B$.

pseudomallei

Table 3.3 (b) Oligonucleotides designed based on plasmid pDM4

Table 4.1 Summary of wzm gene that was deleted in B. pseudomallei 


\section{LIST OF FIGURES}

PAGES

Figure 2.1 Genetic organization of B. pseudomallei K96243 capsular

polysaccharide cluster located at the sites $3327179 \mathrm{bp}$ and

3359841 bp of the Chromosome 1 of B. pseudomallei K96243.

Figure 2.2 Genetic organization of B. pseudomallei, E. coli K5, H.

27

influenzae type $\mathrm{b}$, and $N$. meningtidis group B capsule gene

clusters

Figure 3.1 Annealing positions and nucleotide positions of primers used in this study

Figure 4.1 Schematic diagram of unmarked deletion of $w z m$ in

Burkholderia pseudomallei

Figure 4.2 Growth curve of both B. pseudomallei strain UKMS-01 and

CW-01 grown in LB medium

Figure 4.3 Growth curve of both B. pseudomallei strain UKMS-01 and

CW-01 grown in M9 medium

Figure 4.4 Role of wzm gene in B. pseudomallei biofilm formation

Figure 4.5 Effects of $\Delta w z m$ mutant on desiccation stress response in

B. pseudomallei

Figure 4.6 Sensitivity of wild type and $\Delta w z m$ mutant strains towards

different concentrations of hydrogen peroxide

Figure 4.7 Effects of osmotic stress on wzm gene in wild type and $\Delta w z m$ mutant strains 


\section{LIST OF PLATES}

PAGES

$\begin{array}{lll}\text { Plate 4.1 DNA gel electrophoresis results showing successful } & 61\end{array}$ amplification of upstream gene fragment of $w z m$ and downstream gene fragment of $w z m$

Plate 4.2 DNA gel electrophoresis results showing successful 62 amplification of the ligated fragment of both upstream and downstream regions fragments of wzm gene

Plate 4.3 DNA gel electrophoresis results showing digestion of pCW-easy 63 and pDM4 using restriction enzymes SpeI and $X b a \mathrm{I}$

Plate 4.4 DNA gel electrophoresis results depicting the PCR products of both mutant and wild type screened using primers wzmUSDSSCR-F and wzmUSDS-SCR-R

Plate 4.5 DNA gel electrophoresis results showing the PCR products of chloramphenicol resistance gene

Plate 4.6 DNA gel electrophoresis results showing the PCR products of wzm gene using wzm-SCR-F and wzm-SCR-R primers

Plate 4.7 Transmission electron microscopy of both B. pseudomallei strain

UKMS-01 (A) and B. pseudomallei strain CW-01 (B).

Plate 4.8 Scanning electron microscopy of both B. pseudomallei strain

UKMS-01 (A) and B. pseudomallei strain CW-01 (B) 


\section{Symbols and Abbreviations}

\begin{tabular}{|c|c|}
\hline$\%$ & percentage \\
\hline${ }^{\circ} \mathrm{C}$ & degree Celsius \\
\hline$\lambda$ & lambda clone \\
\hline$\mu g$ & micro gram \\
\hline$\mu 1$ & micro litre \\
\hline $\mathrm{ABC}$ & ATP Binding Cassette \\
\hline ATP & adenosine triphosphate \\
\hline bp & base pair \\
\hline BSA & bovine serum albumin \\
\hline $\mathrm{CaCl}_{2}$ & calcium chloride \\
\hline cat & chloramphenicol resistance gene \\
\hline CFU & colony forming units \\
\hline CPS & capsular polysaccharide \\
\hline $\mathrm{Da}$ & Dalton \\
\hline DMSO & dimethyl sulfoxide \\
\hline DNA & deoxyribonucleic acid \\
\hline dNTP & deoxyribonuclecoside triphosphate \\
\hline EDTA & ethylenediaminetetraacetatic acid \\
\hline EPS & exopolysaccharide \\
\hline $\mathrm{EtBr}$ & ethidium bromide \\
\hline et al. & et alia (and others) \\
\hline
\end{tabular}




\begin{tabular}{|c|c|}
\hline $\mathrm{g}$ & gram \\
\hline$g$ & gravity \\
\hline GDP & glucose diphosphate \\
\hline GSP & general secretory pathway \\
\hline $\mathrm{HCl}$ & hydrochloride acid \\
\hline IPTG & isopropyl $\beta$-D-1- thiogalactopyranoside \\
\hline IVET & in vivo gene expression technologies \\
\hline $\mathrm{kb}$ & kilo base pair \\
\hline $\mathrm{kDa}$ & kilo Dalton \\
\hline $\mathrm{KH}_{2} \mathrm{PO}_{4}$ & potassium dihydrophosphate \\
\hline LB & Luria Bertani \\
\hline $\mathrm{L}$ & litre \\
\hline LD & lethal dose \\
\hline LOS & lipooligosaccharide \\
\hline LPS & lipopolysaccharide \\
\hline M & molar \\
\hline $\mathrm{MgSO}_{4}$ & magnesium sulphate \\
\hline Min & minute \\
\hline $\mathrm{mL}$ & mililitre \\
\hline $\mathrm{mM}$ & milimolar \\
\hline M & molar \\
\hline Mфs & macrophages \\
\hline Mab & monoclonal antibody \\
\hline $\mathrm{Mb}$ & mega base \\
\hline
\end{tabular}




\begin{tabular}{|c|c|}
\hline $\mathrm{N} / \mathrm{A}$ & not applicable \\
\hline $\mathrm{NaCl}$ & sodium chloride \\
\hline $\mathrm{Na}_{2} \mathrm{HPO}_{4}$ & sodium hydrogen phosphate \\
\hline NCBI & National Center for Biotechnology Information \\
\hline $\mathrm{NH}_{4} \mathrm{Cl}$ & ammonium chloride \\
\hline nt & nucleotide \\
\hline ntp & nucleotide position \\
\hline OD & Optical Density \\
\hline OPS & O-polysaccharide \\
\hline ori & origin of replication \\
\hline $\mathrm{PC}$ & phosphatidylcholine \\
\hline PCR & polymerase chain reaction \\
\hline PEG & polyethylene glycol \\
\hline PLC & phospholipase C \\
\hline PMNs & human polymorphonuclear cells \\
\hline ppm & part per million \\
\hline pmol & pico mole \\
\hline $\mathrm{PVC}$ & polyvinyl chloride \\
\hline rRNA & ribosomal ribonucleic acid \\
\hline rpm & revolution per minute \\
\hline$s a c \mathrm{~B}$ & levan sucrase gene \\
\hline $\mathrm{sec}$ & second \\
\hline SEM & standard error of mean \\
\hline STM & signature-tagged mutagenesis \\
\hline
\end{tabular}


TAE

TTSS

TSS

UV

$\mathrm{w} / \mathrm{v}$

V

VC

$\mathrm{v} / \mathrm{v}$

X-GAL tris acetate acid EDTA

type III secretion system

transformation and storage solution

ultra violet

weight per volume

volt

viable count

volume per volume

bromo-chloro-indolyl-galactopyranoside 


\title{
PEMBINAAN DAN PENCIRIAN MUTAN DELESI wzm
}

Burkholderia pseudomallei

\begin{abstract}
Abstrak
Dalam Burkholderia pseudomallei, patogen yang menyebabkan 'melioidosis', kumpulan kluster gen yang berfungsi mengekod polisakarida kapsul tersebut terletak pada kromosom pertama. Secara keseluruhannya, terdapat sejumlah 22 gen pada kluster ini dan di kalangan gen-gen kapsul dalam gen kluster ini, gen wzm masih tidak dikaji secara keseluruhan. Jujukan asid amino gen wzm menunjukkan similariti yang tinggi terhadap CtrC (Neisseria Meningitidis), BexB (Haemophilus Influenzae) dan KpsM (Escherichia coli). Untuk mengkaji fungsi gen $w z m$, mutan isogenik gen $w z m$ dibentuk dan dianalisiskan secara in vitro serta dibandingkan dengan strain jenis liar. Daripada penemuan yang didapati, mutan menghasilkan kurang biofilm berbanding dengan strain jenis liar. Selain itu, mutan lebih sensitif terhadap pengeringan dan stres oksidatif daripada strain jenis liar. Namun, tiada perbezaan yang signifikan dilihat untuk keduadua mutan dan strain jenis liar dalam sensitivi terhadap osmolariti dan keadaan acid. Di samping itu, mikroskopi elektron penskanan menunjukkan permukaan sel-sel bakteria mutan didapati "kasar" berbanding dengan strain jenis liar. Akan tetapi, tiada perbezaan fenotip dapat diperhatikan dengan mikroskopi elektron transmisi apabila sel-sel bakteria untuk kedua-dua mutan dan strain jenis liar dibandingkan.
\end{abstract}




\title{
CONSTRUCTION AND CHARACTERIZATION OF A Burkholderia pseudomallei wzm DELETION MUTANT
}

\begin{abstract}
In Burkholderia pseudomallei, a pathogen that causes melioidosis, the gene cluster that encodes for capsular polysaccharide are located in chromosome one. There are 22 genes in this cluster and among the capsular genes in the cluster, the wzm gene has not been studied thoroughly. The amino acid sequence of $w z m$ shows high similarity to CtrC (Neisseria Meningitidis), BexB (Haemophilus Influenzae) and KpsM (Escherichia coli). To study the function of wzm gene, an isogenic mutant of wzm gene was generated and analyzed in comparison with the wild type strain. From the findings, the mutant produced less biofilm compared to the wild type strain. Furthermore, the mutant was more sensitive towards desiccation and oxidative stress than the wild type strain. However, no significant difference was observed for both mutant and wild type strains in their sensitivity towards high osmolarity and acid conditions. Moreover, scanning electron microscopy showed that the bacterial cells of the mutant strain have "rough" surface compared to the wild type strain. However, no phenotypic difference could be observed using transmission electron microscopy when both bacterial cells of both mutant and wild type strains were compared.
\end{abstract}




\section{Chapter 1}

\subsection{Introduction}

Burkholderia pseudomallei is a gram negative rod-shaped bacterium that causes melioidosis to both human and animals. Among the signs and symptoms that are caused by this disease in human are septicaemia and pneumonia (Cheng and Currie, 2005). Study on the pathogenesis of this fastidious bacterium has attracted the attention of scientists as melioidosis has been reported to be endemic in various parts of the world and $B$. pseudomalle $i$ was reported to be resistant to many antibiotics (Cheng and Currie, 2005).

To understand the molecular and cellular basis of pathogenesis of $B$. pseudomallei, many researchers had started to identify virulence determinants at both proteomic and genetic levels. Among the virulence determinants that were identified

were phopholipase C (Korbsrisate et al., 1999), flagella (DeShazer, 1997) and lipopolysaccharide (DeShazer et al., 1998)

Capsular polysaccharide which is one the virulence determinants in $B$. pseudomallei has the potential to be utitilized as a vaccine (Sarkar-Tyson et al., 2007). The genetic organization of capsular polysaccharide in B. pseudomallei has been identified by Reckseidler-Zenteno et al. (2001) and Holden et al. (2004). The functions of the genes that are located in the cluster were annotated by the latter. Previous studies have shown that capsular polysaccharide is involved in the virulence of $B$. pseudomallei 
in Syrian hamster and mice (Reckseidler et al., 2001; Atkins et al., 2002; Cuccui et al., 2007). Apart from these in vivo animal studies, the capsular polysaccharide may protect the B. pseudomallei from phagocytosis by reducing levels of complement C3 deposition.

It has been shown in previous studies that inactivation using signature-tagged mutagenesis of wzm gene had led to the decrease in survival in mice (Cuccui et al., 2007). The wzm gene was chosen for this study among the genes in the capsular polysaccharide cluster as this gene was not well studied compared to the other capsular genes in the cluster. Hence, in this study, B. pseudomallei UKMS-01, a local animal isolate from sheep is used to investigate the role of $w z m$ gene in harsh conditions. The approach of this research is to construct a markerless and in-frame deletion of wzm mutant of B. pseudomallei and use a few in vitro studies which are osmotic stress assay, desiccation survival assay and biofilm formation assay to study the phenotypic characteristics of the $\Delta w z m$ mutant in comparison with the wild type strain. In addition, the sensitivity of $\Delta w z m$ mutant towards oxidative and acidic conditions is also investigated. Moreover, the surface and the internal structures of the bacterial $\Delta w z m$ mutant cells will be viewed using scanning and transmission electron microscopy to determine whether there are changes in cellular surface as well as the internal structures after the wzm gene is disrupted. 


\section{Chapter 2}

\subsection{Literature review}

\subsection{Burkholderia pseudomallei}

Burkholderia pseudomallei is generally classified as a gram negative, facultative anaerobic, motile and rod shaped bacteria (Wiersinga et al., 2006, Holden et al., 2004, Dance, 2002). It is formerly known as Bacillus pseudomallei or Pseudomonas pseudomallei, and is later re-named as Burkholderia pseudomallei in 1992 based on 16S rDNA sequence (Currie et al., 2004). Burkholderia pseudomallei has been documented by many researchers as a known causative agent of melioidosis, a disease that can cause acute illness in both humans and animals (Gilad et al., 2007).

B. pseudomallei is motile, due to the existence of lophotrichous flagella (DeShazer et al., 1997). This bacterium has the ability to grow on various types of organic matters such as in carbohydrates, amino acids and fatty acids. At the same time, the morphology the $B$. pseudomallei colony can be positively identified although it may vary from rough to smooth wrinkled and may either show white or brown pigmentation (Stone, 2007). It can grow in any growth medium with temperatures ranging from $18^{\circ} \mathrm{C}$ to $42^{\circ} \mathrm{C}$, with the optimum temperature being $37^{\circ} \mathrm{C}$ (Tong et al., 1996). Nevertheless, the B. pseudomallei has been shown to have a rapid growth curve at $42^{\circ} \mathrm{C}$ in the any growth medium and this in turn can cause a depletion or shortage of nutrients within 48 hours and will eventually form a layer of sediment on the plate. 
The optimal $\mathrm{pH}$ for the growth of bacteria was reported to be in the range of $\mathrm{pH}$ 5 to 8 . It was also reported that rapid bacterial inactivation occurs when the $\mathrm{pH}$ is below 4.5 (Tong et al., 1996). In addition, studies have shown that B. pseudomallei is able to survive when exposed to solutions with less than $2.5 \%$ of sodium chloride. However, the bacteria tend to be inactive when exposed to solutions that are more than $2.5 \%$ sodium chloride (Inglis and Sagripanti, 2006). This is opposed to the study done by Pumirat et al. (2009), which mentioned that $B$. pseudomallei can survive in a salty concentration of more than $2.5 \%$. So far, no other studies were conducted on the survival rate of the particular bacteria in seawater but there were reports of melioidosis in survivors of the tsunami disaster that occurred on the $26^{\text {th }}$ December 2004. Those infected were believed to have directly contacted $B$. pseudomallei through their lungs by ingesting contaminated flood water supply (Chierakul et al., 2005). There were reports regarding the use of chlorine to treat drinking water to eliminate the B. pseudomallei. Studies conducted by Howard and Inglis (2003) showed that a concentration of 1000 ppm of chlorine can eradicate B. pseudomallei in drinking water. However, this may not be commercially viable as 1000 ppm of chlorine may cause more harm to human health instead. Furthermore, this bacterium can only survive for 7.75 minutes after exposure to UV light (Tong et al., 1996).

The genome of B. pseudomallei strain K96243, a clinical isolate from Thailand had been sequenced and analysed by Wellcome Trust Sanger Institute, United Kingdom. B. pseudomallei has two main chromosomes, namely, chromosome 1 and chromosome 2 which are $4.1 \mathrm{Mb}$ and $3.2 \mathrm{Mb}$ in size respectively (Holden et al., 2004). A large percentage of coding sequence in chromosome 1 has been associated with core functions 
like cell growth and metabolism while chromosome 2 entails more extensive coding sequences that are involved in accessory functions such as survival and adaptation to the environment (Holden et al., 2004). In addition, the National Center for Biotechnology Information currently has listed another 20 genome sequences and among the 20 , three were fully annotated. The three strains are strains 1106a, 1710a (Thai clinical isolates) and 668 (an Australian clinical isolate) (Adler et al., 2009).

The genomic DNA of B. pseudomallei strain K96243 has 16 genomic islands that take up to $6 \%$ of the whole genome (Holden et al., 2004). Tumapa et al. (2008) demonstrated that there is variation in the presence of genomic islands among different B. pseudomallei isolates. However, the presence of a specific island does not correlate with the virulence of the isolate. The paper by Tumapa et al. (2008) presented only a few representative islands and strains. There is a possibility that other studies may identify striking differences in terms of genomic characteristics between clinical and environmental isolates. By performing phylogenetic studies, it was demonstrated that $B$. pseudomallei is not so closely related to B. thailandensis than to B. mallei. This suggested that the evolution of $B$. pseudomallei is more recent compared to other members of the Burkholderia genus (Ou et al., 2005).

By comparing the genomic, transcriptional and proteomic levels of strain $B$. pseudomallei K96243 and B. pseudomallei 15682, there were significant intrinsic differences between both strains ( $\mathrm{Ou}$ et al., 2005). From the data obtained, it was suggested that horizontal gene transfer or gene loss events had occurred as about $43 \%$ of the gene expression differences were associated with genes that are not present in one or 
the other strain. Furthermore, about $38 \%$ of the global proteomic differences were attributed to strain-specific isoforms of proteins expressed in these two strains (Ou et al., 2005). These findings correlate with the results obtained in another two studies that observed the genome-wide variability between B. pseudomallei K96243 and $1026 \mathrm{~b}$ strains (DeShazer, 2004) and between B. pseudomallei K96243 and B. mallei (Fushan et al., 2005). From all these findings gathered, it can be deduced that variation in phenotypes that are related to growth rate, environmental resistance and virulence may be due to the molecular variation in different B. pseudomallei strains (Ou et al., 2005).

\subsection{Habitat}

B. pseudomallei is reported to thrive through saprophytic means. It inhibits stagnant waters or soils, for example, in paddy fields or in flooded areas (Chaowagul et al., 1989). This explains why it was prevalent among rice farmers and helicopter pilots during the Vietnam War, as most of them were exposed to contaminated soil through ingestion and open wounds (Sanford, 1995). The bacterium was also found to be endemic in Thailand (Leelarasamee 2000), Malaysia (Puthucheary et al., 1992), Singapore (Chan et. al., 1985; Lim et al., 1997) and northern Australia (Cheng et al., 2000; Currie et al., 2000). Besides that, sporadic cases were also reported in Southern Taiwan (Shih et al., 2009), North, Central and South America (Inglis et al., 2006), India (Saravu et al., 2008), Africa, the Caribbean, and the Middle East (Dance, 2000).

Incidence of melioidosis that occurred in certain parts of the world, however, remains woefully unknown. This is especially in third world countries. This could be 
due to the fact that some reported cases were poorly documented, under reported or even unreported due to limited resources and unsuitable facilities in some laboratories (Dance, 2002).

\subsection{Melioidosis}

One of the reasons why B. pseudomallei generated a world wide interest is due to the fact that it is a potential agent of melioidosis, which can indirectly cause a broader spectrum of chronic illnesses in both humans and animals alike (Gilad et al., 2007). A person could be infected easily by $B$. pseudomallei through simple means of ingestion of contaminated materials, open cuts or wounds, abrasions or even through inoculation of infected needles during laboratory experiments by researcher themselves (White, 2003). Once infected with $B$. pseudomallei, it may stay dormant in the host body for years without showing any obvious physical or bodily symptoms (Cheng and Currie, 2005). Examples of reported cases include cases of American soldiers who returned from the Vietnam War, only to start showing symptoms of melioidosis after 30 years. The mortality rate of melioidosis is high and relapses are not uncommon as the disease can affect almost every organ in the host body (Sanford, 1995). Up till now, there is still no vaccine for the prevention of $B$. pseudomallei infection and an infected person is likely to suffer from either acute septicaemia (blood poisoning) or pneumonia (lung infections) (Deshazer et al., 1998, Reckseidler et al., 2001). Wiersinga et al. (2006) also reported that this septicaemic form of melioidosis involves a rapid onset and death is inevitable usually during the first 12 to 24 hours. 
Therefore, the incidence of melioidosis should not be taken lightly as it could spiral out of control as it can affect anyone. Furthermore B. pseudomallei has been classified as being a potential bio-agent to be used in future bioterrorism attacks.

\subsection{Melioidosis in animals}

Melioidosis affects animals as much as human. So far, there have been reports showing that animals such as birds, dogs, goats, kangaroos, pigs, camels, horses, cats, rats and dolphins are being infected by melioidosis caused by B. pseudomallei (Cheng and Currie, 2005). Although there is still no incidence of melioidosis being transmitted from animals to humans, precautions have to be observed at all times. For example, face masks and gloves should be worn during handling of infected animals. Meanwhile, farmers should also be prudent and not hesitant to cull infected live stock though loss is expected as it may cause serious loss of human lives later on.

\section{$2.5 \quad$ Treatment of melioidosis}

Treatment of melioidosis is challenging due to the fact that $B$. pseudomallei itself is resistant to certain antibiotics such as gentamicin and streptomycin (Chaowagul et al., 1989). On top of that, it has also been reported that B. pseudomallei could survive in soil and water for many years, and therefore, must have a certain adaptive mechanism which allows them to continue to survive in harsh and stressful environments (Pumirat et al., 2009). Proteomics studies conducted by Pumirat et al. (2009) showed the changes in

protein secretions in B. pseudomallei under high salt (sodium chloride) concentration 
stress. It was reported that bacteria induced with a high salt environment had a 19-fold increase in a beta-lactamase-like protein which render it resistant to beta-lactam antibiotics, and hence, increases its survival rate.

Despite this, treatment of melioidosis is not impossible and the percentage of recovery increases with early detection and proper diagnosis. There were many cases of patients being successfully treated with various types of antibiotics and these include penicillins and cephalosporins (Cheng and Currie, 2005). Generally, the treatment would be conducted in two stages; the antibiotic being administered intravenously in multiple doses until the steady state of drugs in blood level is achieved. This would then be followed by giving the patients drugs orally to prevent further recurrence or relapse (Cheng and Currie, 2005).

Current studies supporting successful treatments of melioidosis include a study conducted by Simpson et al. (1999), whereby ceftazidime or imipenem were administered intravenously, after the onset of the disease. Nevertheless, the easiest route of administration, the oral route, is still lacking data to support its effectiveness. Despite this, there are evidence in mice studies showing that animals administered with cotrimoxazole as pre-exposure and post-exposure prophylaxis had longer survival rate, compared to the control group (without administration of antibiotics) and those administered with amoxicillin or clavulanic acid (Cheng and Currie, 2005). 


\subsection{Diagnosis of melioidosis}

To diagnose the incidence of melioidosis, an effective method is highly sought after for the fast delivery of correct dosage/ medicament to the infected patients. One of the most popular means to diagnose melioidosis is by utilizing the Ashdown medium (Ashdown, 1979). Ashdown medium is a highly selective medium that selects for $B$. pseudomallei. To carry this out, selective specimens were normally taken from patients' blood, urine, sputum, throat or pus afflicted areas and were then cultured on 5\% blood agar (usually horse blood agar) to isolate the bacteria. The medium is then observed through phenotypic means for the appearance of B. pseudomallei colonies. The method is simple but the drawback is that the medium is not commercially available and not rapidly obtainable for patients from non-endemic countries like the United States or in western countries (Inglis et al., 2006). Besides that, the procedure is also time consuming and may not be viable for clinically chronic patients (Kaestli et al., 2007; Chaowagul et al., 1989). Nevertheless, this method is still being used, and remains the 'gold standard' in diagnosing melioidosis due to its relative cheap cost and high efficacy.

A unique monoclonal antibody (Mab) which is specific to the $30-\mathrm{kDa}$ protein of B. pseudomallei has been developed by Pongsunk et al. (1999). The specific monoclonal antibody has been proven in both in vitro and in vivo (mice) studies to directly agglutinate with 243 clinical isolates of the B. pseudomallei but not with other Gram negative bacteria except $B$. mallei. A closely related method involves a study in developing a rapid multiplex immunofluorescent assay method to detect antibodies 
against B. pseudomallei. The method will detect antibodies against the lipopolysaccharide (LPS) layer of B. pseudomallei should they be present in the obtained clinical samples (Iihara et al., 2007).

There are various publications on molecular methods for the detection of $B$. pseudomallei. These methods involved PCR analysis of primers targeting regions in $16 \mathrm{~S}$ and $23 \mathrm{~S}$ rRNA genes, $16 \mathrm{~S}-23 \mathrm{~S}$ intergenic region, flagellin gene fliC and Type III secretion gene cluster (Lew and Desmarchelier, 1994; Dharakul et al., 1996; Bauernfeind et al., 1998; Gal et al., 2005; Merritt et. al., 2006). PCR-based method is reported to be accurate and produces fewer discrepancies in diagnosing melioidosis (Merritt et al., 2006). Apart from the normal PCR methods, some scientists has evaluated real-time PCR to obtain more reliable and rapid results (Meumann et al., 2006; Novak et al., 2006; Supaprom et al., 2007).

\subsection{Virulence determinants of Burkholderia pseudomallei}

The huge magnitude of the disease caused by this pathogen may imply that this bacterium utilizes a broad range of virulence factors as means of survival in the infection of animals. It is therefore essential to investigate the roles of virulence factors to understand the pathogenesis of $B$. pseudomallei. To date, the virulence factors in this fastidious bacterium are currently understudied compared to other pathogenic bacteria. Elucidation of these virulence determinants in $B$. pseudomallei is currently the main focus of study in the scientific community. A better understanding of these virulence factors can form a rational basis in producing novel vaccines and therapies in curing 
melioidosis. The completion of B. pseudomallei K96243 genome sequencing by Sanger Institute, genomic sequencing analysis using bioinformatics and the development of genetic tools had facilitated identification and isolation of putative virulence factors (Holden et al., 2004; Reckseidler-Zenteno et al., 2003). Genetic techniques that were used in identifying genes associated with virulence factors include Tn5 transposon mutagenesis (DeShazer et al., 1997; Burtnick, et al., 2001), counter-selection markers that facilitate allelic exchange (Moore et al., 1999; Brown et al., 2004; Burtnick and Woods, 1999, Lopez et al., 2009) and signature-tagged mutagenesis using animal infection models (Atkins et al., 2002, Moore et al., 2004). Apart from the reported genetic manipulation methods, subtractive hybridization was also introduced in search for novel virulence factors (Brown and Beacham, 2000; Reckseidler et al., 2001).

In order to study the virulence factors in B. pseudomallei, animal models had been developed. These animal models include BALB/c mice (Leakey et al., 1998; Hoppe et al., 1999; Liu et al., 2002; Jeddeloh et al., 2003;), Syrian hamster (Brett et al., 1997), diabetic rats (Woods et al., 1993), guinea pigs (DeShazer et al., 1998), pigs (Najdenski et al., 2004) and Caenorhabditis elegans (O' Quinn et al., 2001; Gan et al., 2002).

The diabetic rat model using intraperitonal route of infection was devised following the correlation of diabetes mellitus and melioidosis (Woods et al., 1993). This model had been used by many researchers to study a number of putative $B$. pseudomallei virulence factors with some success (Sexton et al., 1994; DeShazer et al., 1997; Jones et al., 1997; DeShazer et al., 1998). DeShazer et al. (1998) also utilized guinea pig as an 
animal model by using intraperitonal route of infection to compare the lipopolysaccharide mutants with the wild type B. pseudomallei $1026 \mathrm{~b}$ strain. However, there is no subsequent use of guinea pigs in any literature reported for the study of virulence determinants. Brett et al. (1997) had reported that Syrian hamster were highly susceptible to $B$. pseudomallei when the animal was infected via intraperitonal route with an $\mathrm{LD}_{50}<10 \mathrm{CFU}$. Subsequent studies had reported the use of Syrian hamster to study the putative virulence factors (DeShazer et al., 1997; Jones et al., 1997; DeShazer et al., 1998; DeShazer et al., 1999; Moore et al., 1999; Reckseidler et al., 2001; Ulrich et al., 2004, Warawa and Woods, 2005).

With the employment of genetic tools and animal studies, a number of virulence determinants were identified. The identified virulence factors that are involved in the pathogenesis of B. pseudomallei are as listed in Table 2.1 . 
Table 2.1 : List of virulence factors that are identified in B. pseudomallei (Adapted from Adler et al. (2009)

\begin{tabular}{|c|c|}
\hline Virulence factors & References \\
\hline Capsule & Reckseidler-Zenteno et al. (2005) \\
\hline Lipopolysaccharide (LPS) & $\begin{array}{l}\text { DeShazer et al. (1998); Burtnick and } \\
\text { Woods (1999) }\end{array}$ \\
\hline Flagella & $\begin{array}{l}\text { DeShazer et al. (1997); Chua et al. (2003); } \\
\text { Chuaygud et al. (2008) }\end{array}$ \\
\hline Type III secretion systems (Bsa) & Stevens et al. (2002); Boddey et al. (2006) \\
\hline Quorum Sensing & $\begin{array}{l}\text { Valade et al. (2004); Song et al. (2005); } \\
\text { Lumjiaktase et al. (2006) }\end{array}$ \\
\hline Pili & $\begin{array}{l}\text { Essex-Lopresti et al. (2005); Brown et al. } \\
\text { (2002); Boddey et al. (2006) }\end{array}$ \\
\hline Efflux pumps & Chan and Chua (2005) \\
\hline Siderophore & Loprasert et al. (2000) \\
\hline Exoproducts* & $\begin{array}{l}\text { DeShazer et al.(1999); Gauthier et al. } \\
(2000)\end{array}$ \\
\hline Morphotype switching & Chantratita et al. (2007) \\
\hline
\end{tabular}

*Exoproducts are secreted factors which are proteases, lipases, lecithinases and haemolysins (Ashdown and Koehler, 1990). 


\subsubsection{Secreted Antigens}

The identified extracellular virulence factors are thermolabile toxin, protease, antigens with lipase and lecithinase activities, haemolysin and water soluble siderophore. Although these putative virulence factors were identified, they are not well characterized.

Several studies that were published between the years 1955 and 1964 indicated that intraperitoneal (i.p.) injections of filter sterilized B. pseudomallei supernatants were lethal to both mice and hamsters. This experiment had suggested that B. pseudomallei produce a lethal toxin (Nigg et al., 1955). Ismail et al. (1987) later had partially purified a $31 \mathrm{kDa}$ thermolabile toxin. This protein was shown to be able to inhibit DNA and protein synthesis, and to be lethal in mice. However, subsequent researchers were unable to reproduce this finding using filter sterilized B. pseudomallei culture to test on animal models (Brett and Woods, 2000).

Haase et al. (1997) had identified another cytolethal toxin (CLT) in $B$. pseudomallei and the isolates from goat and patients with melioidosis encephalitis produced higher toxin as compared to the isolates from soil. Furthermore, Haubler et al. (1998) demonstrated that a 762 Da heat-stable toxin produced cytotoxic effects on phagocytic (HL60) and non-phagocytic (HeLa) cell lines. This toxin showed haemolytic activity when incubated with erythrocytes (Haubler et al., 1998). O'Quinn et al. (2001) and Gan et al. (2002) had conducted studies using C. elegans which suggested that toxin produced by $B$. pseudomallei failed to have deleterious effect on this model organism. These findings were supported by Balaji et al. (2004) whereby filter sterilized $B$. 
pseudomallei supernatants did not kill the worms but live bacteria were lethal to $C$. elegans. Even though B. pseudomallei had been shown to produce exotoxins, there were no reports on characterization of these toxins at the molecular level.

Apart from toxins, B. pseudomallei was shown to secrete biologically active proteins such as hemolysin, protease, lipase and lecithinase (Ashdown and Koehler, 1990) and iron-acquiring siderophores (Yang et al., 1991). Protease and lipase as secreted antigens were further demonstrated by Sexton et al. (1994) and Korbsrisate et al. (1999) respectively by purifying and characterizing these proteins. DeShazer et al. (1999) generated mutants with complete loss of protease, lipase and lecithinase activities using transposon mutagenesis system. From the results obtained, the type II general secretory pathway (GSP) gene cluster was identified but no structural genes of protease, lipase or lecithinase were identified (DeShazer et al., 1999). There was no significant difference between the generated mutants and wild type in terms of virulence when the B. pseudomallei GSP mutant was tested on Syrian hamsters (DeShazer et al., 1999).

There are many reports in identifying proteases in B. pseudomallei. Among them are the studies conducted by Sexton et al. (1994). The findings revealed a purified 36 $\mathrm{kDa}$ metalloprotease showing optimal activity at $60^{\circ} \mathrm{C}$ and $\mathrm{pH} 8$ (Sexton et al., 1994). A few years later, a $47 \mathrm{kDa}$ B. pseudomallei serine metalloprotease designated as MprA was characterized by Lee and Liu (2000). N-terminal sequence of the protease that was purified by Sexton et al. (1994) existed in the predicted amino acid sequence of MprA, thus suggesting that these two proteins were the same proteases (Sexton et al., 1994; Lee and Liu, 2000). Valade et al. (2004) demonstrated that $\Delta m p r A$ mutant did not show any reduction in survival in mice via intraperitoneal and intranasal routes of entry and this 
indicated that MprA was not a virulence determinant in mice (Valade et al., 2004). In 2001, a serine metalloprotease with $52 \mathrm{kDa}$ in size that was characterized by Ling et al. (2001) was highly dependent on calcium ions and showed optimal activity at $38^{\circ} \mathrm{C}$ and $\mathrm{pH}$ 9. This $52 \mathrm{kDa}$ metalloprotease was able to digest immunoglobulins, transferring, albumin, myosin and actin (Ling et al., 2001). Gautheir et al. (2000) reported that there was no correlation between protease production in $B$. pseudomallei and virulence in BALB/c mice. Based on the findings by Gautheir et al. (2000) and DeShazer et al. (1999), it is suggested that exoproducts that are protease, lipase and lecithinase play a minor role in B. pseudomallei pathogenesis.

Based on the bioinformatic analysis of the B. pseudomallei K96243 genomic sequence, three phospholipase C (PLC) enzymes were identified and designated as PLC1, PLC-2 and PLC-3 (Holden et al., 2004). The enzymes PLC-1 and PLC-2 were acidic in nature and were able to hydrolyse lipids, phosphatidylcholine (PC) and sphingomyelin (Korbsrisate et al., 2007). It had been demonstrated that $\Delta p l c-1, \Delta p l c-2$ and a double knockout $\Delta p l c-1$ plc-2 mutants showed decrease in PC-PLC activity (Korbsrisate et al., 2007). Thus, this indicated that these genes encoded functional enzymes. However, there was no complete loss of PC-PLC activity, suggesting that PLC-3 was also likely to be functional. In addition, Tuanyok et al. (2006) demonstrated that the virulence of $\Delta p l c-3$ mutant had decrease in hamsters. The $\Delta p l c-3$ gene was shown to be highly upregulated in comparison to its expression in in vitro grown bacteria when DNA microarray analysis was used to analyse $B$. pseudomallei isolated from hamsters (Tuanyok et al., 2006). Moreover, PC-PLC which was in vivo expressed in $E$. coli can induce $\operatorname{IgM}$ antibody production in patients with melioidosis using 
Western blotting (Korbsrisate et al., 1999). Hence, this indicates that this lipase might be involved in intracellular survival and cell-to-cell spread of B. pseudomallei in the host (Korbsrisate et al., 1999).

Ashdown and Koehler (1990) managed to identify two hemolysins after assessing hemolytic activities of 100 B. pseudomallei strains. Among the 100 strains, 4\% of the strains had high hemolytic activity on sheep blood agar plates while the rest demonstrated low hemolytic activity (Ashdown and Koehler, 1990). In 2007, three ATPbinding cassette transport systems that were involved in exporting hemolysins were predicted from B. pseudomallei K96243 genome (Harland et al., 2007). To date, the roles of hemolysin are still not clear. Hence, characterization in the molecular level is important to understand the virulence of B. pseudomallei.

\subsubsection{Cell-walled associated antigens}

Besides secreting antigens as part of its strategy to impose virulence on other organisms, the B. pseudomallei is also known to produce cell-walled associated antigens such as flagella, pili, LPS and EPS. The flagella has long been hypothesized by many to be important to $B$. pseudomallei as it renders the cell motile and therefore, enabling it to move around freely in search of a conducive environment to thrive and spread virulence. Thus, Vorachit et al. (1995) has proven the existence of flagella and shown the variable expression of pili on B. pseudomallei by using electron microscopy. Furthermore, DeShazer et al. (1997) had identified 19 unique genetic loci that aid motility by performing mutagenesis. Bioinformatic analysis of B. pseudomallei K96342 genome further the identification of 13 gene clusters that are responsible for the synthesis of type 
I fimbriae, type IV pili and Tad-like pili (Adler et al., 2009). The synthesis of a $39.1 \mathrm{kDa}$ flagellum protein is controlled by fliC gene (DeShazer et al., 1997). There are conflicting evidences on the involvement of flagella towards virulence.

Studies conducted by DeShazer et al. (1997) and Wikraiphat et.al (2009) showed that $\Delta$ fliC B. pseudomallei $1026 \mathrm{~b}$ transposon mutant failed to reduce virulence in $\mathrm{BALB} / \mathrm{c}$ mice as compared to the wild type when the diabetic rat or Syrian hamster was infected through the intraperitoneal route. However, Chua et al. (2003) showed that $B$. pseudomallei $\mathrm{KHW} \Delta f l i C$ mutant reduce in survival through intranasal or intraperitoneal routes in BALB/c mice but not in the $C$. elegans model of infection. The factors that contribute to the conflicting data are the usage of different animal models, different modes of infection and different types of mutants generated.

As mentioned earlier, $B$. pseudomallei has also been reported to have structure on its surface known as pili. There are eight type IV pili-associated loci in the $B$. pseudomallei K96243 genome but only one type IV A pilin gene, pilA, exists on the genome (Essex-Lopresti et al., 2005). B. pseudomallei strain K96243 pilA mutant demonstrated reduced adhesion to epithelial cell lines and reduced virulence in $C$. elegans animal model and in BALB/c mice that were infected through intranasal route but not intraperitoneal route (Essex-Lopresti et al., 2005). Studies that were conducted by Boddey et al. (2006) showed that two B. pseudomallei $\Delta$ pilA mutants generated in strains 08 and K96243 had variation in in pilA expression, microcolony formation and cell adhesion. Nevertheless, pilA expression in strain 08 mutant was temperature regulated and is important for microcolony formation expression of pilA in strain 08 mutant was also not essential for adhesion to cultured human cells (Boddey et al., 2006). 
Meanwhile, the LPS of the B. pseudomallei consists of 2 types of $O$ polysaccharides, which is aptly named as type I-OPS and type II O-PS (Perry et.al, 1995). B. pseudomallei mutants without the type II O-PS was shown to be susceptible to $30 \%$ human serum killing through the bactericidal activities (DeShazer et al., 1998). In 2006, a further identification of type III O-PS and type IV O-PS has been reported (Sarkar-Tyson et.al, 2007). Mice which were challenged with type III O-PS and type IV O-PS mutants showed increased mean times to death (approximately 11.6 days) as compared to those challenged with the wild type (3 days). Moreover, immunization with all polysaccharide mutant strains also resulted in delayed time to death, compared to the control group (Sarkar-Tyson et al., 2007).

Another type of cell-walled associated antigen of B. pseudomallei is the exopolysaccharide (EPS). Up to date, there are a number of studies which identified the presence of these structures. One of the more well known EPS, a linear tetrasaccharide repeating galactose units, was shown to exist only in $B$. pseudomallei and not in $B$. thailandensis (Kawahara et al., 1998; Masoud et al., 1997; Steinmetz et al., 1995). Since B. thailandensis does not cause virulence, it is then suggested that the EPS plays a role in causing virulence.

\subsection{Burkholderia pseudomallei capsular polysaccharide}

The polysaccharide capsule is the structure that encapsulates and 'surrounds' the outer-most layer of the bacterium. It interacts with the existing environment and therefore, plays an important role in protecting the bacterium from harsh conditions as 
well as to give rise to causing virulence in other living beings.

B. pseudomallei extracellular polysaccharide has been classified into 2 major categories, (a) capsular polysaccharides (CPS), the polysaccharide closely in contact with the bacteria cell and (b) slime polysaccharides which is loosely associated with the cell respectively (Whitfield, 1995). It is difficult to differentiate between both types since CPS may sometimes resemble the slime polysaccharides when they are being 'released' from the particular cell (Whitfield, 1995). Moreover, CPS also contains lipopolysaccharides (LPS) which are similar to other types of polysaccharides found on the surface of the cell (Whitfield, 1995).

\subsubsection{Roles of bacterial capsule in Burkholderia pseudomallei}

Bacterial capsule in each pathogenic bacterium has its own function(s). Although the role of capsular polysaccharide in B. pseudomallei is still not satisfyingly clear, the capsule basically helps the bacteria in terms of survival as well as to cause virulence.

Previous studies have shown that capsular polysaccharide plays a vital role in virulence by using in vivo animal models such as hamsters and mice. Virulence studies conducted by Reckseidler et al. (2001) and Atkins et al. (2002) demonstrated that $\Delta w c b B$ and $\triangle w c b E$ mutants showed reduction in survival with more than $10^{5}$ fold when the mutants were exposed to hamsters and mouse models intraperitoneally and intraveneously. In addition to that, there were also studies that utilize signature tagged mutagenesis to identify genes from the capsule operon that were critical in causing diseases and virulence in mice (Cuccui et al., 2007). Inactivation of the genes $w c b B$, 
$w c b C$ and $w c b N$ resulted in reduced survival of these mutants in mice (Cuccui et al., 2007). More recently, Wikraiphat et al. (2009) did a comparative in vivo and in vitro analysis to determine the effects of 3 different types of B. pseudomallei mutants (without lipopolysacccharide, without capsule and without flagelin) in causing virulence in BALB/c mice and in both human polymorphonuclear cells (PMNs) and macrophages (Mфs). The lipopolysaccharide and capsule mutants, which were generated through molecular means, were reported to demonstrate a significant decrease in virulence in both mice models as well as in the presence of human PMNs and Mфs, suggesting that both lipopolysaccharide and capsule are highly associated with the virulence of the bacterium (Wikraiphat et al., 2009).

On the other hand, there were also studies which indicated the importance of capsular polysaccharide in protecting the $B$. pseudomallei from host serum cidal activity and opsonophagocytosis by reducing levels of complement C3 deposition (ReckseidlerZenteno et al., 2005). Another similar study was conducted by Wikraiphat et al. (2009) in which the acapsular B. pseudomallei mutant was exposed to human PMNs and Mфs. The experiment showed a decreased level in bacteria residual numbers as compared to the wild type (with capsule), suggesting that without the presence of capsule, the bacteria is more susceptible to intracellular killing by the host's defence systems. Besides that, Wikraiphat et al. (2009) also reported that the presence of the $B$. pseudomallei capsule provided a mediated resistance towards histatin and lactoferrin, suggesting that the capsule itself is important for the resistance towards certain antimicrobial peptides. 
On top of that, B. pseudomallei capsular polysaccharide mutant has also been identified as a possible candidate for vaccine therapy (Sarkar-Tyson et al., 2007). Mice that were vaccinated with $\Delta w c b H$ mutants had higher levels of survival with $70 \%$ of mice surviving at day 35 as compared to mice that were vaccinated with wild type strain which showed $40 \%$ survivors (Sarkar-Tyson et al., 2007). Thus, this suggested that immunization with killed capsular polysaccharide mutant strains may confer immunity against B. pseudomallei.

Other suggested functions of the bacterial capsule which have yet to be determined in $B$. pseudomallei include its involvement in the prevention of desiccation, adherence for colonization and resistance to specific host immunity (Roberts, 1996).

\subsubsection{Genetic organization of capsular polysaccharide gene cluster of $B$. pseudomallei}

According to the B. pseudomallei genomic sequence, the genes that are responsible for the synthesis and export of capsular polysaccharide in B. pseudomallei are located between nucleotides number 3327179 and 3359841 of the Chromosome 1 of B. pseudomallei K96243 (Holden et al., 2004). There are 22 genes altogether in this cluster (Figure 2.1). The functions of these genes were annotated by Sanger Institute as shown in table 2.2 (Holden et al., 2004). The capsular polysaccharide gene cluster was shown to have high percentage of similar in identity to the capsular clusters of other bacteria like Escherichia coli, Neisseria meningitidis and Haemophilus influenzae (Reckseidler-Zenteno et al., 2009) This gene cluster, however, does not have genes 


\section{B. pseudomallei K96243 Chromosome 1}

wcbT $w c b S$ scbR $w c b Q$ wcbP $w c b O$ wcbN $w c b M$ gmhA $w c b L$ wcbK $w c b J$ wcbI wcbH wcbG wcbF wcbE wzt2 wzm wcbD manB wcbC wcbB wcbA

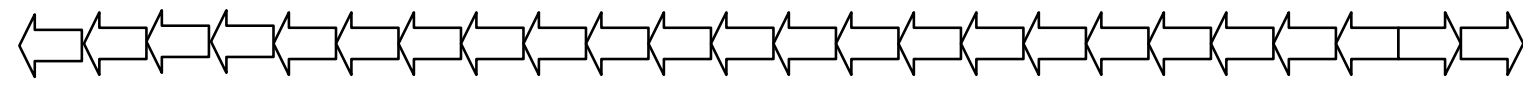

Figure 2.1: Genetic organization of B. pseudomallei K96243 capsular polysaccharide cluster. located at the sites 3327179 bp and 3359841 bp of the Chromosome 1 of $B$. pseudomallei K96243. This capsule cluster is approximately 30kb in size. Genes are not drawn to scale. (Adapted from Reckseidler-Zenteno et al., 2001; Cuccui et al., 2007) 